\title{
Genetics of Postharvest Longevity and Quality Traits in Late Generation Crosses of Antirrhinum majus L.
}

\author{
Jaime A. Weber ${ }^{1}$, William J. Martin², and Dennis P. Stimart ${ }^{3}$ \\ Department of Horticulture, University of Wisconsin-Madison, 1575 Linden Drive, Madison, \\ WI 53706
}

\begin{abstract}
AdDitional INDEX WORDS. cut flower longevity, vase life, postharvest keeping quality, narrow-sense heritability, snapdragon, genotypic correlation, phenotypic correlation

Abstract. Progeny of $158 \mathrm{~F}_{5} \times \mathrm{F}_{5}$ crosses of Antirrhinum majus (snapdragon) selected within and among cut flower postharvest longevity $(\mathrm{PHL})$ categories $($ long $=12.6-16.8$ days, middle $=9.3-12.1$ days, and short $=4.8-8.9$ days $)$ were evaluated for PHL and quality traits. Results were compared with previous studies involving $F_{2} \times F_{2}$ progeny, and $F_{3}$, $F_{4}$, and $F_{5}$ inbred lines. Heritability of PHL in $F_{5} \times F_{5}$ progeny $(0.77 \pm 0.11)$ agrees with that of inbred lines $(0.79$ to 0.81) but is higher than in $F_{2} \times F_{2}$ progeny (0.41). Therefore, selection for increased PHL should progress more rapidly and predictably through application of inbred lines rather than $F_{2}$ individuals. Significant differences between $F_{5} \times F_{5}$ progeny PHL categories confirm PHL is heritable with a significant additive component. Heritabilities of quality traits in A. majus are high, suggesting selection for quality traits should progress without difficulty. Phenotypic and genotypic correlations of PHL with quality traits are not consistently significant across PHL studies in A. majus. Discrepancies between studies suggest most traits may not be correlated to PHL or are subject to strong environmental influence.
\end{abstract}

United States cut flower sales are $\$ 1.1$ billion of the nearly $\$ 5.1$ billion floriculture industry (Jerardo, 2004). Imported cut flowers are $61 \%$ of U.S. sales while domestic cut flower production is declining. The reliance on international cut flowers reinforces the importance of postharvest longevity. Prolonged PHL may also increase consumer demand for cut flowers (Reid et al., 1995; Rogers, 1963).

Cut flower PHL is affected by genetic and nongenetic components (Halevy and Mayak, 1979). Conditions preharvest and especially postharvest like temperature, light and humidity affect cut flower PHL (Halevy and Mayak, 1979; Holley, 1963; Urban et al., 1995). Postharvest techniques focus on minimizing water loss, respiration rate, microbial infection, and ethylene production and sensitivity (Gosxczyńska and Rudnicki, 1988) and affect PHL more than preharvest conditions. Effectiveness of postharvest treatments and handling techniques vary by species and cultivar (Halevy and Mayak, 1979; Holley, 1963; Urban et al., 1995). Chemical treatments like silver thiosulfate (STS), an ethylene inhibitor (Coorts, 1973), and 8-hydroxyquinoline (8-HQ), a microbial growth inhibitor (Rogers, 1973), are used commercially to increase cut flower PHL. However, neurotoxic STS and carcinogenic 8-HQ may be banned (Nell, 1992; Ohkawa et al., 1999), making research on genetic improvement of PHL imperative.

Genetic variability in PHLexists in Dendrobium Sw. (Bobisud and Kamemoto, 1982) and Rosa ×hybrida L. (De et al., 1999). PHL is heritable with significant additive gene effects in Cal-

\footnotetext{
Received for publication 27 Jan. 2005. Accepted for publication 5 Apr. 2005. A note of gratitude to Peter Crump, Univ. of Wisconsin-Madison, for statistical consultation during preparation of this manuscript. Use of trade names does not imply endorsement of the products named or criticism of similar ones not named.

${ }^{1}$ Graduate Research Assistant

${ }^{2}$ Research Associate

${ }^{3}$ Professor and Chair of Department. To whom reprint requests should be addressed. Email address: dstimart@wisc.edu
}

listephus chinensis (L.) Nees (Patil and Rane, 1995), Dianthus caryophyllus L. (Burchi et al., 1999), Gerbera Gmel. (de Jong and Garretsen, 1985; Harding et al., 1981; Wernett et al., 1996a, 1996b), Lilium L. (van der Meulen-Muisers et al., 1999), Rosa L. (De et al., 1999), and Tulipa L. (van Eijk and Eikelboom, 1980). Selection increased PHL $\approx 3.5$ d in both $D$. caryophyllus (Onozaki et al., 2001) and Gerbera xhybrida Hort. (Wernett et al., 1996a). Successful PHL selection in G. xhybrida and D. caryophyllus along with the additive gene effects and moderate to high heritabilities for PHL found in various species suggest selection of prolonged PHL in cut flower crops is promising.

Antirrhinum majus is valued eighth in the U.S. cut flower market, with sales of \$14.6 million in 2003 (Jerardo, 2004). Difficulties in shipping and ethylene sensitivity decrease quality and PHL in A. majus. Cut flower PHL is increased by pulsing cut stems with STS and holding cut stems in sucrose and 8-hydroxyquinoline citrate (HQC) solutions (Rogers, 1992). Genetic PHL improvement would decrease dependence on these toxic chemical compounds and improve A. majus cut flower quality, which may increase consumer demand.

Studies in A. majus suggest PHL is a quantitative trait with significant additive and dominant components (Martin and Stimart, 2003, 2005; Schroeder, 2000; Schroeder and Stimart, 2001). A minimum of two to four genes appear to control the trait (Schroeder, 2000). PHL heritability estimates were 0.30 in $\mathrm{F}_{2}, \mathrm{BC}_{1}$, and $\mathrm{BC}_{2}$ generations (Schroeder, 2000), 0.41 in $\mathrm{F}_{2} \times \mathrm{F}_{2}$ progeny (Martin and Stimart, 2003), 0.79 in $\mathrm{F}_{3}$ inbred lines, and 0.81 in $F_{4}$ and $F_{5}$ inbred lines (Martin and Stimart, 2005). The increase in heritability with further inbreeding suggests genetically pure breeding material will provide a better prediction of progeny performance. Although PHL is an important trait, cut flowers must possess additional quality traits for consumers (van der MeulenMuisers and van Oeveren, 1997). Significant phenotypic (Martin and Stimart, 2003 and 2005; Schroeder and Stimart, 2001) and genotypic (Martin and Stimart, 2005) correlations of PHL with quality traits of A. majus are found in early generation crosses, backcrosses and inbred lines. 
This study used $\mathrm{F}_{5} \times \mathrm{F}_{5}$ progeny of $A$. majus to estimate heritability for PHL and quality traits; to estimate phenotypic and genotypic correlation coefficients of quality traits with PHL; and to compare results with previous studies.

\section{Materials and Methods}

Commercial inbred lines of cut flower A. majus were evaluated in 1991 and 1992 for cut flower postharvest longevity (PHL). P1, $16.3 \mathrm{~d}$ PHL, was crossed with P2, $3.0 \mathrm{~d}$ PHL, to produce an $\mathrm{F}_{1}$ (Stieve and Stimart, 1994). The $\mathrm{F}_{1}$ was self-pollinated to produce an $\mathrm{F}_{2}$ population in Fall 1998. Four hundred eighty-five plants were selected randomly and self-pollinated to create $\mathrm{F}_{3}$ families. Of these families, 155 were selected randomly and advanced to the $\mathrm{F}_{5}$ generation through single-seed descent. In fall, winter, and spring of 2001-02, $\mathrm{F}_{3}, \mathrm{~F}_{4}$, and $\mathrm{F}_{5}$ generations of 105 inbred lines were evaluated for PHL and quality traits in replicated plantings (Martin and Stimart, 2005).

To more accurately select lines for the current study, a PHL index (Falconer and Mackay, 1996) was calculated utilizing expected intergenerational genetic correlations and determined heritability estimates from $\mathrm{F}_{3}, \mathrm{~F}_{4}$, and $\mathrm{F}_{5}$ generations (Martin, 2002). Thirty-eight $F_{5}$ inbred lines were selected randomly: 14 lines within the $25 \%$ highest indices (12.99 to 15.58), 10 within the $50 \%$ of indices about the mean (10.19 to 11.54$)$, and 14 within the $25 \%$ lowest indices (5.28 to 9.45 ). Selected lines were re-categorized into $\mathrm{F}_{5}$ PHL categories for statistical analysis: 15 lines within the $25 \%$ longest lived (12.6 to $16.8 \mathrm{~d}$ ), 12 within 1.5 $\mathrm{d}$ about the mean (9.3 to $12.1 \mathrm{~d}$ ) and 11 within the $25 \%$ shortest lived ( 4.8 to $8.9 \mathrm{~d}$ ). The selected $\mathrm{F}_{5}$ inbreds were intermated in a half-diallel mating scheme to create $\mathrm{F}_{5} \times \mathrm{F}_{5}$ progeny in Spring and Summer 2002.

Not all cross combinations could be evaluated due to resource limitations. Thus, a sample of $158 \mathrm{~F}_{5} \times \mathrm{F}_{5}$ progeny was chosen among and within PHL categories for evaluation of PHL and quality traits in Fall 2002 and 2003. In Fall 2002, 79 $\mathrm{F}_{5} \times \mathrm{F}_{5}$ progeny, $\mathrm{P} 1, \mathrm{P} 2$, and $\mathrm{F}_{1}(\mathrm{P} 1 \times \mathrm{P} 2)$ were grown under standard forcing procedures (Rogers, 1992) in a polyethylene greenhouse at the Univ. of Wisconsin-Madison using a randomized complete-block design (eight blocks, three replications/genotype/block). Due to low seed production, crosses were recreated for the 79 previously evaluated $\mathrm{F}_{5} \times \mathrm{F}_{5}$ progeny using remnant $\mathrm{F}_{5}$ seed in Spring and Summer 2003 for Fall 2003 evaluation. Seventy-nine additional $\mathrm{F}_{5} \times \mathrm{F}_{5}$ progeny along with $20 \mathrm{~F}_{5} \times \mathrm{F}_{5}$ progeny evaluated in Fall $2002, \mathrm{P} 1, \mathrm{P} 2$, and $\mathrm{F}_{1}(\mathrm{P} 1 \times \mathrm{P} 2)$ were grown in three adjacent sections of a glasshouse at the Univ. of Wisconsin-Madison using a randomized complete block design (six blocks, three replications/genotype/block) in Fall 2003.

In both plantings, seeds were germinated in cells of 96-cell $\left(65 \mathrm{~cm}^{3}\right)$ flats using a growing medium of equal volumes peat, perlite and composted soil. Seedlings were transplanted into single cells of 96-cell $\left(65 \mathrm{~cm}^{3}\right)$ flats when the first true leaves appeared. After the third set of true leaves developed, seedlings were transplanted into $1250 \mathrm{~cm}^{3}$ plastic pots and spaced on 22$\mathrm{cm}$ centers. Supplemental lighting from 1000-W high-pressure sodium lamps, $27 \mu \mathrm{mol} \cdot \mathrm{m}^{-2} \cdot \mathrm{s}^{-1}$ at bench level, was provided from 0600 through $2400 \mathrm{HR}$. Two hundred $\mathrm{mg} \cdot \mathrm{L}^{-1} \mathrm{~N}$ of Peter's fertilizer (20N-8.7P-16.6K) was applied every other week (Scott's Sierra Horticultural Products Co., Marysville, Ohio).

Plants were harvested at the soil line when five florets opened and transported in distilled water to the laboratory. Buds at harvest was recorded as the number of florets showing color prior to an- thesis. Plant height, distance from inflorescence tip to stem base, and plant height nonfloral, distance from lowest floret to stem base, were measured, and floral region size was calculated from their difference. Floral region density was calculated by dividing the number of buds and florets open at harvest by the floral region size. Floral region uniformity was determined on a visual scale ( 1 = excellent to 5 = poor; Martin and Stimart, 2005). Floret size was recorded as the average distance between the tips of the upper and lower petals of the three lowest florets. Stems were cut to $40 \mathrm{~cm}$ below the lowest floret and the leaves from the bottom 15 $\mathrm{cm}$ of the stem were removed, hereafter termed cut flower. Cut flower weight and stem base diameter were recorded. Cut flower strength was measured as the deviation in $\mathrm{cm}$ at the cut flower tip when held horizontally by the stem's lowest $5 \mathrm{~cm}$.

Cut flowers were held $7.5 \mathrm{~cm}$ apart in a three by five grid placed over a plastic storage container $(34 \mathrm{~cm}$ long $\times 22 \mathrm{~cm}$ wide $\times 15 \mathrm{~cm}$ high) holding $3 \mathrm{~L}$ of distilled $\mathrm{H}_{2} \mathrm{O}$, a depth of $4 \mathrm{~cm}$. The $\mathrm{H}_{2} \mathrm{O}$ level was maintained daily. Containers were placed under constant cool-white fluorescent lighting at $23{ }^{\circ} \mathrm{C}$. Cut flowers were discarded when $50 \%$ of the open florets displayed either a browning/drying or wilting senescence symptom (Marousky and Raulston, 1970). Presence of bentneck was determined by collapse of the floral region. Number of buds and open florets were recorded at discard. Degree of leaf wilt was determined on a visual scale $(1=$ zero to slight wilt, $2=$ moderate wilt, $3=$ high degree of wilt). Days to flower was calculated by the difference between dates of harvest and seed sowing. PHL was calculated by the difference between dates of harvest and discard.

Population statistics for traits, including means, minimums, maximums, and standard deviations; and phenotypic and genotypic correlation coefficients between traits were determined using SAS (Littell et al., 1996). All traits were tested for normal distributions. To account for repetition of some genotypes across years, estimates of genotypic means were made using Best Linear Unbiased Prediction(Bernardo, 2002). Variance components were estimated using SAS mixed model analysis assuming a completely random design with Satterthwaite corrections for degrees of freedom (Satterthwaite, 1946). Narrow-sense heritability estimates for traits were derived from both midparent-offspring regression and analysis of variance (ANOVA) (Falconer and Mackay, 1996; Hallauer and Miranda, 1988). As all genotypes were not repeated and block number varied across plantings, harmonic means were calculated for block $(b=6.75)$ and planting $(\mathrm{p}=1.06)$ for use in ANOVAestimates of heritability. ANOVAremoves environmental and genotype $\times$ environmental error as well as differences in evaluation technique between researchers (Falconer and Mackay, 1996). Thus, ANOVA-derived heritabilities are used for discussion unless otherwise noted. As a large number of genotypes were evaluated, the correlation value required for significance at $P \leq 0.01$ with $\approx 150 \mathrm{df}$ was low at $r=0.21$. Therefore, discussion will focus on traits that are still significant at $r=0.21$ when the standard error of each trait's correlation coefficient is included.

\section{Results and Discussion}

Regression of $\mathrm{F}_{5} \times \mathrm{F}_{5}$ progeny PHL means on midparent value reveals clustering within cross categories (Fig. 1). Transgressive segregants exist within cross categories; a trend also seen in crosses of Asiatic Lilium (van der Meulen-Muisers et al., 1999).

Midparent-offspring regression resulted in a heritability estimate for PHL of 0.54 (Fig. 1 and Table 1), slightly higher than previous ANOVA-derived estimates of 0.41 (Martin and Stimart, 


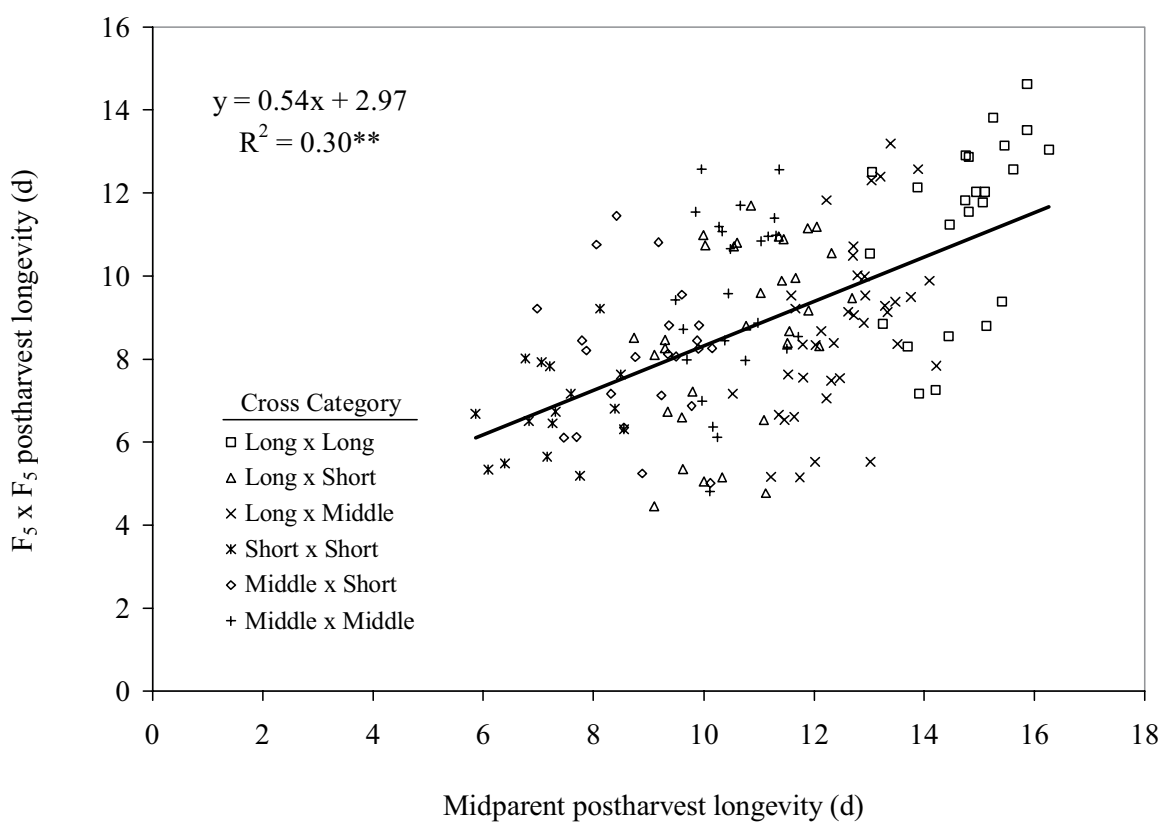

Fig. 1. Regression of $\mathrm{F}_{5} \times \mathrm{F}_{5}$ progeny on midparent values for postharvest longevity of Antirrhinum majus cut flowers. Progeny derived from crosses within and among categories of $\mathrm{F}_{5}$ parents for postharvest longevity: long $=12.6-16.8 \mathrm{~d}$, middle $=9.3-12.1 \mathrm{~d}$, short $=4.8-8.8 \mathrm{~d}$. **Significant at $P \leq 0.01$

Table 1. Heritability estimates from midparent-offspring regression and analysis of variance (ANOVA) for quality traits of $\mathrm{F}_{5} \times \mathrm{F}_{5}$ progenyz of Antirrhinum majus.

\begin{tabular}{|c|c|c|c|c|}
\hline \multirow{2}{*}{$\begin{array}{l}\text { Phenotypic } \\
\text { quality trait } \\
\text { Bentneck }^{w}\end{array}$} & \multicolumn{2}{|c|}{$\begin{array}{l}\text { Midparent-offspring } \\
\text { regression derived } h^{2} \\
\text { and corresponding } R^{2}\end{array}$} & \multicolumn{2}{|c|}{$\begin{array}{c}\text { ANOVA derived } h^{2 y} \\
\text { and corresponding } \\
\text { standard errors }\end{array}$} \\
\hline & --- & --- & 0.44 & 0.13 \\
\hline Buds at discard (no.)v & 0.48 & $0.04^{*}$ & 0.65 & 0.12 \\
\hline Buds at harvest (no.)v & 0.24 & $0.12^{* *}$ & 0.67 & 0.12 \\
\hline Cut flower diameter $(\mathrm{cm})^{\mathrm{u}}$ & 0.67 & $0.31^{* *}$ & 0.87 & 0.11 \\
\hline Cut flower strength $(-\mathrm{cm})^{\mathrm{t}}$ & 0.33 & $0.34^{* *}$ & 0.70 & 0.12 \\
\hline Cut flower weight $(\mathrm{g})^{\mathrm{s}}$ & 0.55 & $0.21^{* *}$ & 0.79 & 0.11 \\
\hline Days to flower $(d)^{r}$ & 0.23 & $0.22^{* *}$ & 0.36 & 0.13 \\
\hline Floral region densityq & 0.03 & $0.06^{* * *}$ & 0.16 & 0.15 \\
\hline Floral region size $(\mathrm{cm})^{\mathrm{p}}$ & 0.14 & $0.02^{\mathrm{NS}}$ & 0.58 & 0.12 \\
\hline Floral region uniformity ${ }^{\circ}$ & 1.24 & $0.50^{* *}$ & 0.71 & 0.12 \\
\hline Floret size $(\mathrm{cm})^{\mathrm{n}}$ & --- & --- & 0.74 & 0.12 \\
\hline Florets open at discard (no.) & 0.29 & $0.24^{* *}$ & 0.70 & 0.12 \\
\hline Leaf wilt ${ }^{\mathrm{m}}$ & --- & --- & 0.75 & 0.12 \\
\hline Plant height (cm) & 0.54 & $0.42^{* *}$ & 0.84 & 0.11 \\
\hline Plant height nonfloral $(\mathrm{cm})^{1}$ & 0.62 & $0.51^{* * *}$ & 0.82 & 0.11 \\
\hline Postharvest longevity $(\mathrm{d})^{\mathrm{k}}$ & 0.54 & $0.30^{* *}$ & 0.77 & 0.11 \\
\hline Senescence symptomi & 0.42 & $0.15^{* *}$ & 0.65 & 0.12 \\
\hline
\end{tabular}

Based on means of $158 \mathrm{~F}_{5} \times \mathrm{F}_{5}$ crosses.

$\mathrm{yh}^{2}=\left(\sigma_{\mathrm{g}}^{2}\right) /\left(\sigma^{2} / \mathrm{pbr}+\sigma_{\mathrm{gb}(\mathrm{p})}^{2} / \mathrm{pb}+\sigma_{\mathrm{gp}}^{2} / \mathrm{p}+\sigma_{\mathrm{g}}^{2}\right)$, derived from ANOVA.

${ }^{\mathrm{x}} \mathrm{SE} \mathrm{h}^{2}=\left[\operatorname{var}\left(\sigma_{\mathrm{g}}^{2}\right)\right]^{1 / 2} /\left(\sigma^{2} / \mathrm{pbr}+\sigma^{2}{ }_{\mathrm{gb}(\mathrm{p})} / \mathrm{pb}+\sigma^{2}{ }_{\mathrm{gp}} / \mathrm{p}+\sigma_{\mathrm{g}}^{2}\right)$.

wisual rating on date of discard $(0=$ no, $1=$ yes $)$.

vUnopened florets with visible color.

u40 $\mathrm{cm}$ below lowest floret.

tDeviation in $\mathrm{cm}$ from horizontal position.

stem cut $40 \mathrm{~cm}$ below lowest floret with lowest $15 \mathrm{~cm}$ of leaves removed.

$\mathrm{r}$ (Date of harvest - date of planting).

qAt harvest, (number of buds + number of open florets) / (plant height - plant height nonfloral).

$\mathrm{P}$ (plant height - plant height nonfloral).

-Visual rating ( 1 = excellent uniformity, 5 = very poor uniformity).

nBottom of lowest petal to top of highest petal on a single floret.

mVisual rating ( $1=$ little or no wilt, $2=$ moderate wilt, $3=$ extreme wilt $)$.

'Soil line to lowest floret.

$\mathrm{k}$ (date of discard - date of harvest).

jVisual rating taken on date of discard (browning/drying $=0$, wilting $=1$ ).

ns, *,**Nonsignificant or significant at $P \leq 0.05$ or 0.01 , respectively.
2003), and 0.30 (Schroeder and Stimart, 2001). Heritability of $F_{5} \times F_{5}$ progeny PHL derived fromANOVA was $0.77 \pm 0.11$ (Table 1) and comparable to A. majus inbred lines (0.79 to 0.81; Martin and Stimart, 2005), Lilium (0.74; van der Meulen-Muisers et al., 1999), and $R$. xhybrida (0.80; De et al., 1999). Lower estimates are reported in $C$. chinensis (0.59; Patil and Rane, 1995), D. caryophyllus (0.51 to 0.59; Burchi et al., 1999), Gerbera jamesonii Bol. ex Adlam. (0.00 to 0.38; Harding et al., 1981), and $G$. xhybrida (0.28; Wernett et al., 1996b). The above studies estimate PHL heritability using different population structures and experimental designs, both of which affect heritability. Therefore, it is difficult to compare heritability estimates from other species and studies.

The PHL heritability estimate for $\mathrm{F}_{5} \times$ $\mathrm{F}_{5}$ progeny suggests strong additive genetic variance (Falconer and Mackay, 1996). Regression of repeated $\mathrm{F}_{5} \times \mathrm{F}_{5}$ progeny from 2002 and 2003 plantings strengthens this assertion (Fig. 2). PHL values were slightly lower in 2003 supporting a significant genotype $\times$ planting interaction in ANOVA. Furthermore, significant differences exist between PHL cross categories with exception of the long $\times$ short and long $\mathrm{x}$ middle, and the long $\times$ short and middle $\times$ short (Fig. 3 ). The significant differences between cross categories additionally reinforce the significant additive component for A. majus PHL reported previously (Martin and Stimart, 2003, 2005; Schroeder and Stimart, 2001).

Distributions of $\mathrm{F}_{5} \times \mathrm{F}_{5}$ and $\mathrm{F}_{2} \times \mathrm{F}_{2}$ crosses are similarly normal implying that variation for PHL present in the $\mathrm{F}_{2}$ remains in the $\mathrm{F}_{5}$ (Fig. 4). Further, $\mathrm{F}_{5} \times \mathrm{F}_{5}$ progeny variability confirms selection for increased PHL using the $\mathrm{F}_{5}$ generation remains possible. The higher PHL heritability estimate in $\mathrm{F}_{5} \times \mathrm{F}_{5}$ progeny $(0.77$, Table 1), vs. $F_{2} \times F_{2}(0.41 ;$ Martin and Stimart, 2003), suggests inbreeding increases predictability and success of selection for PHL. Early vs. late generation testing has been discussed in Zea mays L. since 1935 (Hallauer, 1990). Theoretical calculations conclude correlation between parents and progeny should increase as parents become increasingly inbred (Bernardo, 1991). However, inbreeding beyond the $S_{3}\left(F_{5}\right)$ generation does not sufficiently increase correlation to justify further inbreeding (Bernardo, 1991). In addition, if heritability is low in the $\mathrm{S}_{0}\left(\mathrm{~F}_{2}\right)$ generation, more families must be selected in early generations to obtain the best family (Bernardo, 1992). Similarly, PHL heritability estimates derived from $\mathrm{F}_{2} \times \mathrm{F}_{2}(0.41)$ and $\mathrm{F}_{5} \times \mathrm{F}_{5}(0.77)$ predict increased progeny correlation with parental value in later vs. earlier generations. However, the resources required for inbreeding one or two generations beyond the $\mathrm{F}_{3}$, with PHL heritability estimates of 0.79 in the $F_{3}$ and 0.81 in the $F_{4}$ and $F_{5}$, may not warrant inbreeding beyond the $\mathrm{F}_{3}$.

Heritabilities of quality traits derived from midparent-offspring regression ranged from 0.03 to 1.24 , while heritabilities derived from ANOVA ranged from 0.16 to 0.87 (Table 1). Heritabilities of quality traits were higher when derived from ANOVA than from parent-offspring regression agreeing with previous estimates (Martin and Stimart, 2005). The midparent-offspring derived heritability estimate of 1.24 for floral region uniformity is likely 


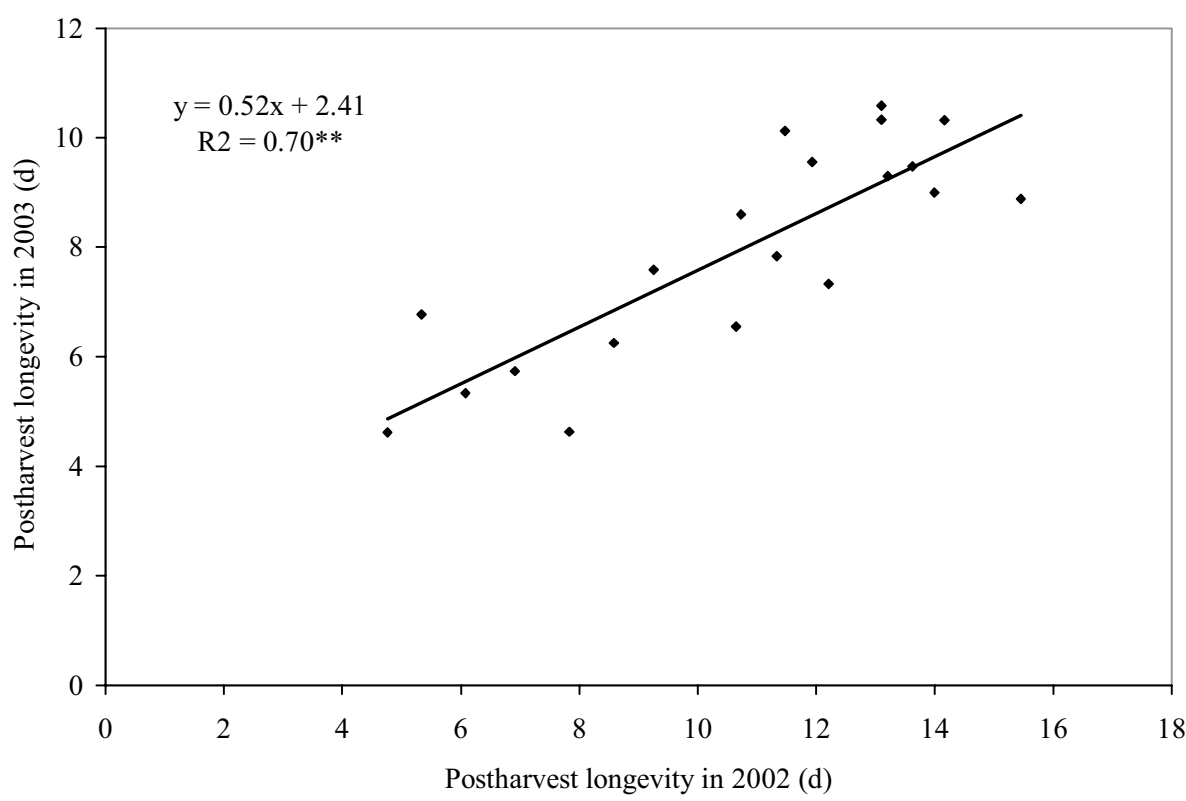

Fig. 2. Regression of cut flower postharvest longevity in $\mathrm{F}_{5} \times \mathrm{F}_{5}$ progeny of Antirrhinum majus grown in Fall 2002 and Fall 2003.

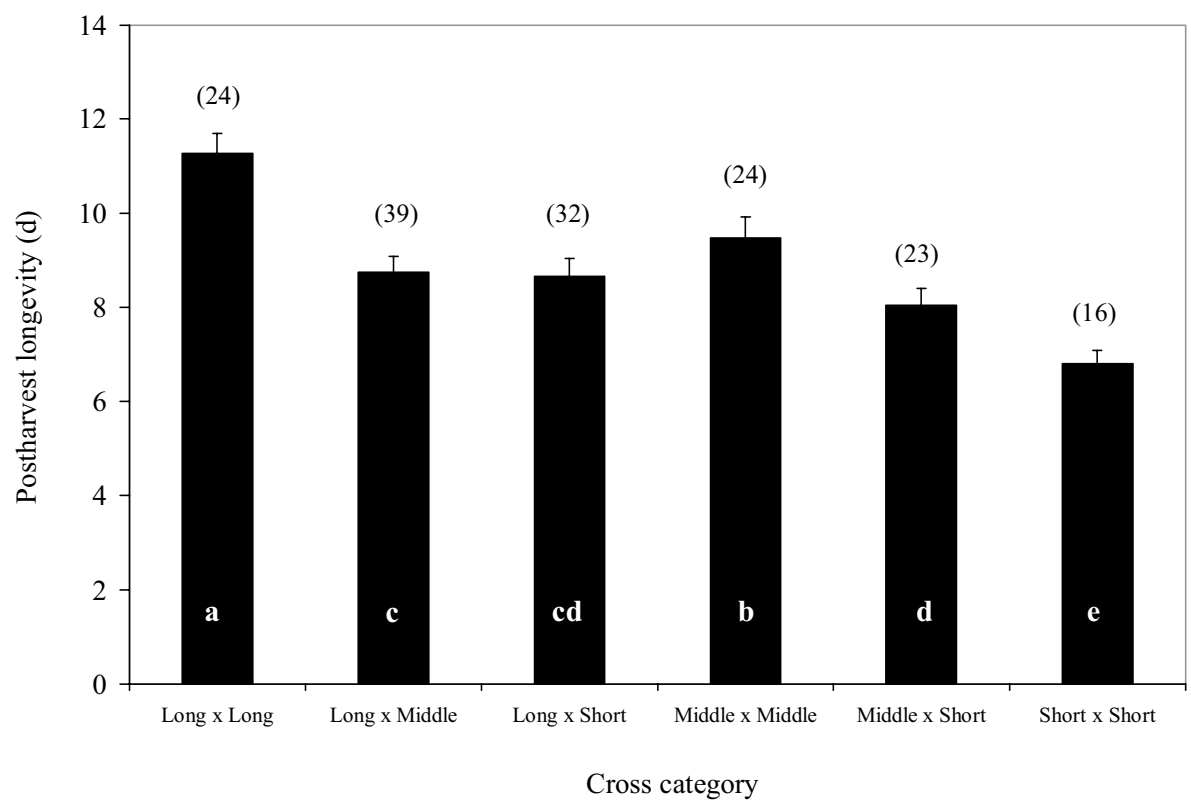

Fig. 3. Average postharvest longevity of cut flowers for $\mathrm{F}_{5} \times \mathrm{F}_{5}$ progeny of Antirrhinum majus. Cross categories derived from crosses within and among categories of $\mathrm{F}_{5}$ parents for postharvest longevity: long $=12.6-16.8$ $\mathrm{d}$, middle $=9.3-12.1 \mathrm{~d}$, short $=4.8-8.8 \mathrm{~d}$. Numbers in parentheses represent number of genotypes evaluated. Letters represent mean separation of cross categories, $\mathrm{LSD}_{0.05}=0.62 \mathrm{~d}$.

an overestimate due to differences between subjective individual rating techniques. This variability is eliminated when estimating heritabilities from ANOVA and therefore, estimates from ANOVA are more accurate.

ANOVA derived heritability estimates of traits evaluated in $\mathrm{F}_{5} \times \mathrm{F}_{5}$ progeny (Table 1) and inbred lines (Martin and Stimart, 2005) agree except for buds at discard, days to flower, and floral region density. The heritability estimate for buds at discard (0.65) is slightly higher in $\mathrm{F}_{5} \times \mathrm{F}_{5}$ progeny than in inbreds ( 0.20 to 0.48$)$. Floral region density $(0.16)$ has a much higher heritability in inbred lines, 0.69 to 0.80 (Martin and Stimart, 2005). However, one parent involved in crosses between $\mathrm{F}_{5}$ lines had a much higher floral region density which may have influenced heritability of the trait by skewing data in the $\mathrm{F}_{5} \times \mathrm{F}_{5}$ progeny. Additionally, heritability of floral region density may be affected by the multiple, environmentally sensitive traits involved in its calculation including buds at harvest, plant height, and plant height nonfloral. Finally, heritability of days to flower is lower in $\mathrm{F}_{5} \times$ $\mathrm{F}_{5}$ progeny $(0.36)$ than inbred lines, 0.63 to 0.72 (Martin and Stimart, 2005). This is likely due to photoperiodic differences between the four response groups of $A$. majus (Dole and Wilkins, 2005). Inbred lines were evaluated in fall, winter and spring, but both populations in this study were evaluated in fall.

Heritability estimates for quality traits of $\mathrm{F}_{5} \times \mathrm{F}_{5}$ progeny are similar to estimates for $C$. chinensis for plant height (0.75), nonfloral height $(0.75)$, cut flower weight (0.67), and buds at harvest (0.65) (Patil and Rane, 1995). Conversely, days to flower in $C$. chinensis (0.64) agrees with that of inbred lines of A. majus (Martin and Stimart, 2005) rather than that in $\mathrm{F}_{5} \times$ $\mathrm{F}_{5}$ progeny. The high heritabilities found in this and other studies for quality traits suggest selection for most quality traits in A. majus is possible and should proceed without difficulty.

Phenotypic traits are significantly correlated with PHL except floral region density $(0.22 \pm 0.08)$, floral region size $(0.22 \pm$ 0.07 ), and plant height $(0.26 \pm 0.08)$ (Table 2). Some traits are autocorrelated to PHL or confounded into the definition of PHL and have been disregarded. These include florets open at discard, buds at discard, and buds at harvest. Florets open at discard $(0.66$ \pm 0.06 ) is incorporated into the definition of PHL; buds at discard $(0.75 \pm 0.05)$ is inversely proportional to florets open at discard; and buds at harvest $(-0.34 \pm 0.08)$ influences the potential number of florets opening. Previously unevaluated traits in $A$. majus, bentneck $(-0.60 \pm 0.06)$, floret size $(-0.31 \pm 0.08)$, and leaf wilt $(-0.76 \pm 0.05)$ are significantly correlated to PHL.

Traits highly correlated with PHL are related to water balance (Table 2). Bentneck $(-0.60 \pm 0.06)$, leaf wilt $(-0.76 \pm 0.05)$, and wilting senescence symptom $(-0.58 \pm$ $0.07)$ are signs of greater water loss through transpiration than uptake through the cut stem. Water imbalance may be due to multiple causes such as microbial plugging of conducting vessels (van Doorn et al., 1989; van Doorn and de Witt, 1991; Zagory and Reid, 1986), physiological stem embolism (Burge et al., 1998; Dai and Paull, 1991; Ichimura et al., 1998; Nakahara et al., 1998; van Doorn et al., 1989), or water loss through dysfunctional stomata (van Doorn, 1997). PHLis increased in wilting A. majus lines when transpiration is reduced (Martin, 2002). Also, recutting A. majus cut flower stems leads to greater and prolonged water uptake and 


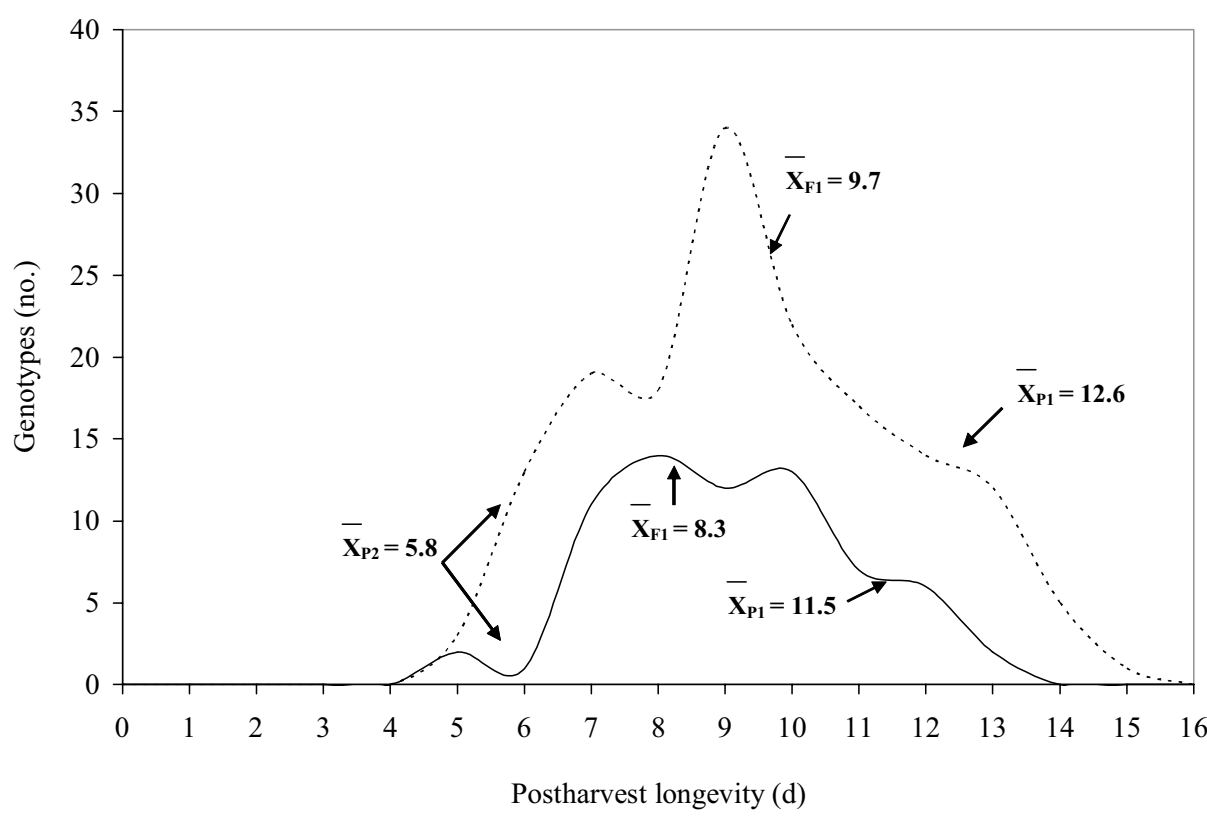

Fig. 4. Distribution of cut flower postharvest longevity in $68 \mathrm{~F}_{2} \times \mathrm{F}_{2}$ progeny $(-)$ and $158 \mathrm{~F}_{5} \times \mathrm{F}_{5}$ progeny (- - - ) of Antirrhinum majus.

significantly extended PHL(Martin, 2002). The high correlations between traits relating to water balance and PHL, considered along with extended PHL by recutting stems or reducing transpiration, suggest water balance plays a crucial role in PHL of A. majus. Comparison with previously reported phenotypic correlations between PHL and quality traits shows senescence symptom is the only trait consistently correlated in all studies (Martin and Stimart, 2003, 2005; Schroeder and Stimart, 2001).

Genotypic correlation coefficients estimate the level of genetic correlation between two traits, removing the environmental correlation found in phenotypic correlations (Falconer and Mackay, 1996). Autocorrelated traits were disregarded as described previously. Genotypic correlations of quality traits with PHL are highly significant for bentneck $(-0.74 \pm 0.13)$, cut flower stem diameter $(-0.41 \pm 0.13)$, floral region density $(-0.52 \pm 0.30)$, floral region size $(-0.50 \pm 0.14)$, floral region uniformity $(-0.52 \pm 0.13)$, floret size $(-0.57 \pm 0.12)$, and senescence symptom $(-0.69 \pm 0.11)$ (Table 2). $\mathrm{F}_{5}$ inbred line PHL was significantly correlated with cut flower strength $(-0.44 \pm 0.04)$ and days to flower $(-0.43 \pm$ 0.04) (Martin and Stimart, 2005). The lack of similar genotypic correlations between PHL and quality traits in the two studies suggests traits may not be as correlated as it appears from correlation coefficient estimation. However, inbred lines have lower dominance and environmental variance, providing more precise correlations (Falconer and MacKay, 1996). Furthermore, all inbred lines were grown over three seasons, which may result in more precise genotypic correlation estimates by accurate removal of environmental influence.

Heritability estimates for PHL and quality traits are high and agree with those of inbred lines of $A$. majus. Therefore, selection for PHL and quality traits is possible and should proceed rapidly and without difficulty. Higher heritability for PHL is estimated in $\mathrm{F}_{5} \times \mathrm{F}_{5}$ progeny than in $\mathrm{F}_{2} \times \mathrm{F}_{2}$ progeny, which confirms the easier prediction of hybrid performance based on crossing later generation inbreds of A. majus. Thus, selection for increased PHL should progress more easily when utilizing genetically pure germplasm, but the time and resources required for inbred development must be considered. Genotypic and phenotypic correlation coefficients of PHL with quality traits in A. majus are not consistently significant between studies. Population structure influences correlations which could lead to differences between studies. The only quality trait of $A$. majus significantly correlated with PHL in this and previous studies is senescence symptom. In addition, traits not previously studied, leaf wilt and bentneck, are highly correlated with PHL, strengthening the importance of water balance in PHL of A. majus.

\section{Literature Cited}

Bernardo, R. 1991. Correlation between testcross performance of lines at early and late selfing generations. Theor. Appl. Genet. 82:17-21

Bernardo, R. 1992. Retention of genetically superior lines during early-generation testcrossing of maize. Crop Sci. 32:933-937.

Bernardo, R. 2002. Breeding for quantitative traits in plants. Stemma Press, Woodbury, Minn.

Bobisud, C.A. and H. Kamemoto. 1982. Se-

lection and inbreeding in amphidiploid Dendrobium (Orchidaceae). J. Amer. Soc. Hort. Sci. 107:1024-1027.

Burchi, G., C. Bianchini, A. Mercuri, G. Foglia, D. Rosellini, and T. Schiva. 1999. Analysis of post-harvest flower life in a cross between carnation cultivars with different ethylene responses. J. Genet. Breeding 53:301-306

Burge, G.K.,E.R. Morgan, I. Konczak, and J.F. Seelye. 1998. Postharvest characteristics of Limonium 'Chorus Magenta' inflorescences. N.Z. J. Crop Hort. Sci. 26:135-142.

Coorts, G.D. 1973. Internal metabolic changes in cut flowers. HortScience 3:195-198.

Dai, J. and R.E. Paull. 1991. Effect of water status on Dendrobium flower spray postharvest life. J. Amer. Soc. Hort. Sci. 116:491-496.

De, L.C., S.D. Wahi, and S.K. Bhattacharjee. 1999. A Post-harvest study of genetic divergence in cut roses. Indian J. Genet. 59:351-356.

de Jong, J. and F. Garretsen. 1985. Genetic analysis of cutflower longevity in Gerbera. Euphytica 34:779-784.

Dole, J.M. and H.F. Wilkins. 2005. Floriculture: Principles and species (2nd ed.). Pearson Prentice Hall, N.J.

Falconer, D.S. and T.F.C. Mackay. 1996. Introduction to Quantitative Genetics (4th ed.). Addison Wesley Longman Limited, Edinburgh Gate, Harlow Essex, England.

Goszczyńska, D.M. and R.M. Rudinicki. 1988. Storage of cut flowers. Hort. Rev. 10:35-62.

Halevy, A.H. and S. Mayak. 1979. Senescence and postharvest physiology of cut flowers, Part 1. Hort. Rev. 1:204-236.

Hallauer, A.R. 1990. Methods used in developing maize inbreds. Maydica 35:1-16.

Hallauer, A.R. and J.B. Miranda. 1988. Quantitative genetics in maize breeding (2nd ed.). Iowa State Univ. Press, Ames.

Harding, J.T., B. Byrne, and R.L. Nelson. 1981. Heritability of cut-flower vase longevity in Gerbera. Euphytica 30:653-657.

Holley, W.D. 1963. Grow keeping quality into your flowers: How to grow flowers that will last, p. 9-16. In: M.N. Rogers (ed.). Living flowers that last: A national symposium. Univ. of Missouri, Columbia.

Ichimura, K., Y. Makusa, T. Fujiwara, K. Kohata, and K. Sato. 1998. Improvement of postharvest life and changes in sugar concentrations by sucrose treatment in bud-cut sweet pea. Bul. Natl. Res. Inst. Veg., Ornamental Plants \& Tea, Japan. 13:41-49.

Jerardo, A. 2004. USDA electronic outlook report from the economic research service: Floriculture and nursery crops outlook. 3 Oct. 2004. 
Table 2. Phenotypic and genotypic correlation coefficients and respective SES of phenotypic quality traits with postharvest longevity of Antirrhinum majus.

\begin{tabular}{|c|c|c|c|c|}
\hline $\begin{array}{l}\text { Phenotypic } \\
\text { quality trait }\end{array}$ & $\begin{array}{l}\text { Phenotypic } \\
\text { correlation } \\
\text { coefficient }^{z}\end{array}$ & $\mathrm{SE}^{\mathrm{y}}$ & $\begin{array}{l}\text { Genotypic } \\
\text { correlation } \\
\text { coefficient }^{\mathrm{x}}\end{array}$ & $\mathrm{SE}^{\mathrm{w}}$ \\
\hline Bentneck (\%) & $-0.60^{* *}$ & 0.06 & $-0.74^{* *}$ & 0.13 \\
\hline Buds at discard (no. $)^{\mathrm{u}}$ & $-0.75^{* *}$ & 0.05 & $-0.80^{* *}$ & 0.09 \\
\hline Buds at harvest (no.) ${ }^{\mathrm{u}}$ & $-0.34^{* *}$ & 0.08 & $-0.34^{* *}$ & 0.15 \\
\hline $\begin{array}{l}\text { Cutflower stem } \\
\text { diameter }(\mathrm{cm})^{\mathrm{t}}\end{array}$ & $-0.30^{* *}$ & 0.08 & $-0.41^{* *}$ & 0.13 \\
\hline $\begin{array}{l}\text { Cutflower stem } \\
\text { strength }(-\mathrm{cm})^{\mathrm{s}}\end{array}$ & $0.35^{* *}$ & 0.08 & $0.18^{*}$ & 0.15 \\
\hline Cutflower weight $(\mathrm{g})^{\mathrm{r}}$ & $-0.52^{* *}$ & 0.07 & $-0.26^{* *}$ & 0.14 \\
\hline Days to flower (d)q & $0.36^{* *}$ & 0.07 & 0.03 & 0.23 \\
\hline Floral region densityp & $0.22^{* *}$ & 0.08 & $-0.52^{* *}$ & 0.30 \\
\hline $\begin{array}{l}\text { Floral region } \\
\text { size }(\mathrm{cm})^{\circ}\end{array}$ & $0.22^{* *}$ & 0.07 & $-0.50^{* *}$ & 0.14 \\
\hline $\begin{array}{l}\text { Floral region } \\
\text { uniformityn }\end{array}$ & $-0.45^{* *}$ & 0.07 & $-0.52^{* *}$ & 0.13 \\
\hline Floret size $(\mathrm{cm})^{\mathrm{m}}$ & $-0.31^{* *}$ & 0.08 & $-0.57^{* *}$ & 0.12 \\
\hline $\begin{array}{c}\text { Florets open at } \\
\text { discard (no.) }\end{array}$ & $0.66^{* *}$ & 0.06 & $0.60^{* *}$ & 0.12 \\
\hline Leaf wilt ${ }^{1}$ & $-0.76^{* *}$ & 0.05 & $-0.24^{* *}$ & 0.15 \\
\hline Plant height $(\mathrm{cm})$ & $0.26^{* *}$ & 0.08 & -0.11 & 0.14 \\
\hline $\begin{array}{l}\text { Plant height } \\
\text { nonfloral }(\mathrm{cm})^{\mathrm{k}}\end{array}$ & $0.40^{* *}$ & 0.07 & 0.10 & 0.14 \\
\hline Senescence symptom ${ }^{j}$ & $-0.58^{* *}$ & 0.07 & $-0.69^{* *}$ & 0.11 \\
\hline
\end{tabular}

"Pearson's correlation coefficient $\left(\mathrm{r}_{\mathrm{xy}}=\sum\left(\mathrm{x}_{\mathrm{i}}-\mathrm{x}.\right)\left(\mathrm{y}_{\mathrm{i}}-\mathrm{y}.\right) /\left[\sum\left(\mathrm{x}_{\mathrm{i}}-\mathrm{x} .\right)^{2}\left(\mathrm{y}_{\mathrm{i}}\right.\right.\right.$ $\left.\left.-\mathrm{y}.)^{2}\right]^{1 / 2}\right)$, determines phenotypic correlation coefficients.

${ }^{y_{S E}}\left(r_{\mathrm{p}}\right)=\left(\left(1-\mathrm{r}_{\mathrm{p}}{ }^{2}\right) /(\mathrm{n}-2)\right)^{1 / 2}$.

${ }^{\mathrm{x}} \mathrm{r}_{\mathrm{A}}=\operatorname{cov}_{\mathrm{xy}} /\left(\sigma_{\mathrm{x}}^{2} \sigma_{\mathrm{y}}^{2}\right)^{1 / 2}$.

${ }^{{ }^{w}} \operatorname{SE}\left(r_{\mathrm{A}}\right)=\left[\left(1-\mathrm{r}_{\mathrm{A}}{ }^{2}\right) /(2)^{1 / 2}\right]\left[\left(\sigma_{\mathrm{h} 2 \mathrm{x}} \sigma_{\mathrm{h} 2 \mathrm{y}}\right) /\left(\mathrm{h}_{\mathrm{x}}^{2} \mathrm{~h}^{2}\right)^{1 / 2}\right]$.

vVisual rating on date of discard $(0=$ no, $1=$ yes $)$.

"Unopened florets with visible color.

$40 \mathrm{~cm}$ below lowest floret.

sDeviation in $\mathrm{cm}$ from horizontal position.

rStem cut $40 \mathrm{~cm}$ below lowest floret with lowest $15 \mathrm{~cm}$ of leaves removed.

q(date of harvest - date of planting).

pAt harvest, (number of buds + number of open florets) / (plant height

- plant height nonfloral).

${ }^{\circ}$ (Plant height - plant height nonfloral).

nVisual rating ( 1 = excellent uniformity, $5=$ very poor uniformity).

mBottom of lowest petal to top of highest petal on a single floret.

${ }^{1}$ Visual rating $(1=$ little or no wilt, $2=$ moderate wilt, $3=$ extreme wilt).

kSoil line to lowest floret.

jVisual rating on date of discard (browning/drying $=0$, wilting $=1$ ).

*, ** Significant at $P \leq 0.05$ or 0.01 , respectively.

<http://www.ers.usda.gov/publications/flo/Sep04/FLO03.pdf>.

Littell, R.C., G.A. Milliken, W.W. Stroup, and R.D. Wolfinger. 1996. SAS system for mixed models. SAS Inst., Cary, N.C.

Marousky, F.J. and J.C. Raulston. 1970. Interaction of flower preservative components and light on fresh weight and longevity of snapdragon flowers. Proc. Fla. State Hort. Soc. 83:445-448.

Martin, W.J. 2002. Postharvest biology and genetics of Antirrhinum majus L., snapdragon. PhD Diss., Univ. of Wisconsin-Madison.

Martin, W.J. and D.P. Stimart. 2003. Early generation evaluation in Antirrhinum majus for prediction of cutflower postharvest longevity. J. Amer. Soc. Hort. Sci. 128:876-880.
Martin, W.J and D.P. Stimart. 2005. Genetic analysis of advanced populations in Antirrhinum majus L. with special reference to cut flower postharvest longevity. J. Amer. Soc. Hort. Sci. 130:434-441.

Nakahara, K., O.K. Kikuchi, S. Todoriki, H. Hosoda, and T. Hayashi. 1998. Role of sucrose in gamma-irradiated Chrysanthemum cut flowers. Biosci. Biotechnol. Biochem. 62:49-53.

Nell, T.A. 1992. Taking silver safely out of the longevity picture. Grower Talks. June:35, 37, 39, 41-42.

Ohkawa, K., Y. Kasahara, and J.-N. Suh. 1999. Mobility and effects on vase life of silver-containing compounds in cut rose flowers. HortScience 34:112-113.

Onozaki, T., H. Ikeda, and T. Yamaguchi. 2001. Genetic improvement of vase life of carnation flowers by crossing and selection. Scientia Hort. 87:107-120.

Patil, S.S.D. and D.A. Rane. 1995. Studies on heritability estimates in China aster. J. Maharashtra Ag. Univ. 20:137-138.

Reid, M.S., M. Moktari, J.H.Lieth, W.G. van Doorn, and R.Y.Evans. 1995. Modelling the postharvest life of cut roses. Acta Hort. 424:137-144.

Rogers, M.N. 1963. We must sell flowers that last: Improved keeping quality is of vital importance, p. 5-8. In: M.N. Rogers (ed.). Living flowers that last: A national symposium. Univ. of Missouri, Columbia.

Rogers, M.N. 1973. A historical and critical review of postharvest physiology research on cut flowers. HortScience 3:189-194.

Rogers, M.N. 1992. Snapdragons, p. 93-112. In: R.A. Larson (ed.). Introduction to floriculture, 2nd ed. Academic, San Diego, Calif.

Satterthwaite, F.E. 1946. An approximate distribution of estimates of variance components. Biom. Bul. 2:110-114.

Schroeder, K.R. 2000. A study on the genetics and physiology of cut flowers postharvest longevity in Antirrhinum majus L. PhD Diss., Univ. of Wisconsin-Madison.

Schroeder, K.R. and D.P. Stimart. 2001. Genetic analysis of cutflower longevity in Antirrhinum majus L. J. Amer. Soc. Hort. Sci. 126:200-204.

Stieve, S.M. and D.P. Stimart. 1994. Genetic analysis of postharvest longevity in Antirrhinum majus L. HortScience 29:435 (Abstr.).

Urban, I., R. Brun, and L. Urban. 1995. Influence of electrical conductivity, relative humidity and seasonal variations on the behaviour of cut roses produced in soilless culture. Acta Hort. 408:101-107.

van der Meulen-Muisers, J.J.M. and J.C. van Oeveren. 1997. Influence of bulb stock origin, inflorescence harvest stage and postharvest evaluation conditions of cut flower longevity of Asiatic hybrid lilies. J. Amer. Soc. Hort. Sci. 122:368-372.

van der Meulen-Muisers, J.J.M., J.C. van Oeveren, J. Jansen, and J.M. van Tuyl. 1999. Genetic analysis of postharvest flower longevity in Asiatic hybrid lilies. Euphytica 107:149-157.

van Doorn, W.G. 1997. Water relations in cut flowers. Hort. Rev. 18:1-85.

van Doorn, W.G. and Y. de Witte. 1991. Effect of bacterial suspensions on vascular occlusion in stems of cut rose flowers. J. Appl. Bacteriol. 71:119-123.

van Doorn, W.G., K. Schurer, and Y. de Witte. 1989. Role of endogenous bacteria in vascular blockage of cut rose flowers. J. Plant Physiol. 134:375-381.

van Eijk, J.P. and W. Eikelboom. 1980. Methods of selection in tulip breeding. Acta Hort. 109:217-225.

Wernett, H.C., T.J. Sheehan, G.J. Wilfret, F.J. Marousky, P.M. Lyrene, and D.A. Knauft. 1996a. Postharvest longevity of cut-flower Gerbera. I. Response to selection for vase life components. J. Amer. Soc. Hort. Sci. 121:216-221.

Wernett, H.C., G.J. Wilfret, T.J. Sheehan, F.G. Martin, T.L. White, G.L. Powell, and C. Wilcox. 1996b. Postharvest longevity of cutflower Gerbera. II. Heritability of vase life. J. Amer. Soc. Hort. Sci. 121:222-224.

Zagory, D. and M.S. Reid. 1986. Role of vase solution microorganisms in the life of cut flowers. J. Amer. Soc. Hort. Sci. 111:154-158. 